\title{
A FOGÁSMÉLYSÉG HATÁSA A MIKROMÉRETÜ FORGÁCSLEVÁLASZTÁS DINAMIKAI SAJÁTOSSÁGAIRA
}

\section{THE INFLUENCE OF DEPTH OF CUT ON THE DYNAMICS OF THE MICRO CHIP REMOVAL PROCESS}

\author{
Balázs Barnabás Zoltán ${ }^{1^{*}}$, Geier Norbert ${ }^{1}$, Poór Dániel István ${ }^{1}$, Pereszlai Csongor ${ }^{1}$, Takács \\ Márton ${ }^{1}$ \\ ${ }^{1}$ Gyártástudomány és -technológia Tanszék, Gépészmérnöki Kar, Budapesti Müszaki és \\ Gazdaságtudományi Egyetem, Magyarország \\ https://doi.org/10.47833/2021.1.ENG.007
}

\section{Kulcsszavak: \\ Mikromarás \\ Forgácsolási erő \\ Frekvenciaanalízis \\ Edzett acél \\ Keywords: \\ Micro-milling \\ Cutting force \\ Frequency analysis \\ Hardened steel}

\section{Cikktörténet:}

Beérkezett 2021. február 20.

Átdolgozva 2021. március 15.

Elfogadva 2021. április 5.

\begin{abstract}
Összefoglalás
A kutatás fö célja a fogásmélység mikromarási folyamat dinamikájára gyakorolt hatásának a vizsgálta az eröjelek elemzésén keresztül. A kísérleteket egy mikromegmunkáló központon, $500 \mu m$ átméröjü, kétélü keményfém maróval hajtottuk végre 50 HRC keménységü edzett acélon. A vizsgálatok nyomán feltártuk a forgácsolási paraméterek és az erök közötti kapcsolatot, valamint azonosítottuk a mikromarást jellemző domináns frekvenciákat.
\end{abstract}

\begin{abstract}
The main aim of this research was to investigate the effect of the depth of cut on the dynamics of the micro-milling through the analysis of force signals. The experiments were performed in a micromachining centre with a two fluted, $500 \mu \mathrm{m}$ diameter carbide micro-milling tool on hardened steel with a hardness of 50 HRC. The investigations revealed the relationship between the cutting parameters and the forces, moreover, the dominant frequencies that characterise the process were identified.
\end{abstract}

\section{Bevezetés}

Az ipar felöl egyre nagyobb igény mutatkozik a miniatür komponensek iránt, ami komoly kihívásokat támaszt a korszerü gyártástechnológiával szemben [1, 2]. A kisméretü alkatrészek előállítására az egyik legkiemelkedőbb technológia a mikromarás, mivel alkalmas az anyagok széles körében, akár komplex 3D geometriák nagypontosságú előállítására is, relatív nagy anyagleválasztási sebesség mellett. Mikromarással jellemzően $1 \mathrm{~mm}$ alatti struktúrákat állítunk elő, mely szármarás esetében az alkalmazható szerszámátmérőket is korlátok közé szorítja. Az erőteljes méretcsökkenés következtében az eljárás számos speciális sajátossággal rendelkezik a hagyományos méretü maráshoz képest, ezért az ott megszerzett tudás számos esetben nem adaptálható közvetlenül [3, 4]. A kisméretű szerszámok relatív nagy ütése és annak az eröhatások következtében történő aránylag nagymértékủ deformációja sokszor nagy kihívást jelent a technológusoknak [2]. A folyamatot relatív erős rezgések, valamint sorjaképződés jellemzi [5-7]. Mikroméretekben a szerszámok viszonylag nagy éllekerekedési sugarának $\left(r_{\beta}\right)$ köszönhetően

\footnotetext{
* Kapcsolattartó szerző. Tel.: +3614632641

E-mail cím: balazs.barnabas.zoltan@gpk.bme.hu
} 
előtérbe kerül a minimálisan leválasztható anyagrétegvastagság $\left(h_{\min }\right)$ problémaköre is. A tudományos publikációk alapján a kettő értéke egymással összefügg, és a kutatók a $h_{\min } / r_{\beta}$ arányt 0,22-0,48 közé helyezik el [3, 8]. A mikroméretü forgácsleválasztás tartományában a fajlagos forgácsolóerő viselkedése is jelentősen eltér a hagyományos méretekhez képest $[9,10]$.

Mikromarásnál a relatív erős rezgések vizsgálatának is kiemelt szerepe van, ugyanis befolyásolja a szerszáméltartamot, valamint az öngerjesztett rezgések kialakulása az elóállított felületek minőségét is jelentősen befolyásolja [11,12], továbbá instabillá teszi a forgácsleválasztási folyamatot [13].

A tudományos publikációk alapján viszonylag kevés kutatás foglalkozik az edzett acélok mikormarásának vizsgálatával [14], ezért - köszönhetően a jó meleg-keménységének, jó kopásállóságnak és szívósságnak [15] - az X40CrMoV5-1 anyagot választottuk a vizsgálatokhoz. Ezt az ötvözetet hagyományos méretekben fröccsöntő szerszámok alapanyagaként is alkalmazzák, mindezek miatt a mikroméretü fröccsöntő szerszámok alapanyagaként is szolgálhat, ami miatt fontos a mikromarás sajátosságai szempontjából történő tanulmányozása is. Rengeteg kutatás irányul a mikromarási folyamat dinamikai vizsgálatára, azonban a fogásmélység hatása és a jellegzetes eröfrekvencia komponensek időbeli változása keveset kutatott téma.

A kutatás fő célkitűzése a fogásmélység folyamat dinamikájára gyakorolt hatásának a vizsgálata edzett acél mikromarása során. Kis fogásmélységek esetén a szerszám sarokrádiusza jelentősen befolyásolhatja a folyamat dinamikai jellemzőit, a különböző fogásmélységek $\left(a_{p}\right)$ esetén pedig a szerszám és a munkadarab nagyobb kontakthossza miatt a súrlódási viszonyok, illetve a szerszámgeometria hatása - például horonyszög - jelentősen eltérhetnek. Emellett további feladatot jelent a különböző $a_{p}$ értékek esetén a jellemző rezgésfrekvenciák azonosítása, valamint azok időbeli változásainak vizsgálata is.

\section{Kísérleti környezet}

A mikromarási folyamat dinamikájának vizsgálata során a fogásmélység hatását tanulmányoztuk az 1. táblázatban látható szisztematikus kísérletterven keresztül, horonymarási stratégia mellett.

1. Táblázat. Kísérletterv

\begin{tabular}{|l|c|c|c|c|}
\hline Faktorok & $v_{c}(\mathrm{~m} / \mathrm{min})$ & $f_{z}(\mu \mathrm{m})$ & $a_{p}(\mu \mathrm{m})$ & Anyag \\
\hline Értékek & 90 & 8 & $25,50,75,100,125,150$ & X40CrMoV5-1 \\
\hline
\end{tabular}

A kísérleteket egy VHTC 130 típusú öttengelyes megmunkálóközponton hajtottuk végre, 500 $\mu \mathrm{m}$ átmérőjü, kétélü, AITiN bevonatos, sarokrádiuszos $(50 \mu \mathrm{m})$ keményfém mikromaróval. A gyártói ajánlást, a korábbi tudományos kutatómunkáinkat, valamint a gép maximális fordulatszámát figyelembe véve $90 \mathrm{~m} / \mathrm{min}$ forgácsoló sebességet alkalmaztunk a vizsgálatok során [16-18]. Az élenkénti előtolást - szintén korábbi kutatásainkra alapozva - $8 \mu \mathrm{m}$-re választottuk [16-18], mivel ez mind a szakirodalom, mind a saját vizsgálatok alapján meghaladja a $h_{\min }$ értékét $[8,19]$. A

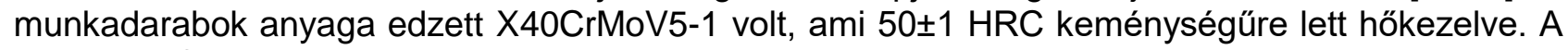
metallográfiai vizsgálatok alapján az anyag homogén struktúrával rendelkezik, amiben egyenletes eloszlású $1 \mu \mathrm{m}$ körüli karbidszemcsék helyezkednek el. Továbbá, a méréseink alapján a munkadarab mikro-keménysége a keresztmetszet és a hossz mentén is egységes.

A vizsgálatok során rögzítettük az erőket, melyhez egy Kistler 9257A háromkomponensű erőmérőt, egy Kistler 5080A töltéserősítőt, valamint egy NI USB-4431 adatgyűjtőt és egy LabVIEW szoftverkörnyezetben készült programot alkalmaztunk.

\section{Eredmények}

\subsection{Erők elemzése}

Az erők elemzése kiemelt fontosságú a mikromarás esetében, mivel az abszolút értékben kis erök is már relatív nagymértékü szerszámdeformációt okozhatnak a kis merevségü mikromarók esetében. Emellett a domináns anyagdeformációs mechanizmusokkal - nyírás, vasalás - is kapcsolatban állnak. Az elemzések során az erőméröcella koordinátarendszernek megfelelően $x, y$ 
és $z$ irányú erőkomponenseket elemeztünk. Ebböl az $F_{y}$ az előtolás irányú erő, az $F_{x}$ az erre, valamint a szerszám tengelyére meröleges irányú erőt, az $F_{z}$ pedig a szerszám tengelyével párhuzamos irányú erökomponenst jelenti. Az értékeléshez LabVIEW szoftverkörnyezetben készült saját fejlesztésű programot alkalmaztunk. Az adatok az állandósult forgácsleválasztás szakaszából származnak, ahol 100 egymást követő fordulat erömaximumainak az átlagai kerültek elemzésre (lásd Egyenlet (1)).

$$
F_{x, y, z}=\frac{\sum_{i}^{100} F_{i}}{100}(\mathrm{~N})
$$

A kísérletek eredményeit az 1. ábra mutatja be. Jól látható, hogy az $F_{x}$ erőkomponens növekszik a fogásmélység növelésével, köszönhetően a növekvő forgácskeresztmetszeteknek. $A z$ $F_{y}$ változása ugyanezen okok miatt hasonló, azonban nagyobb mértékű. Az axiális erő esetében viszont nincsenek ilyen jelentős változások a növekvő fogásmélység következtében. Megfigyelhető, hogy az $a_{p}=25 \mu \mathrm{m}$ és az $a_{p}=50 \mu \mathrm{m}$ esetében az $F_{z}$ komponens a legnagyobb a három közül. Ez azzal magyarázható, hogy a szerszámon lévő kisméretü sarokrádiusz mikroméretekben nem elhanyagolható, mivel arányaiban a fogásmélység nagyságrendjébe esik. Az említett két esetnél az effektív föélelhelyezési szög drasztikusan lecsökken, ami aránylag nagyobb tengelyirányú eröket eredményez. A többi esetben viszont már nem az $F_{z}$ a domináns erőkomponens, mivel a nagyobb fogásmélységeknél a sarokrádiusz hatása kevésbé jelentős, valamint a szerszám horonyszögének a hatása is jobban érvényesül, ami az ellenkező irányba „húzza” az anyagot.

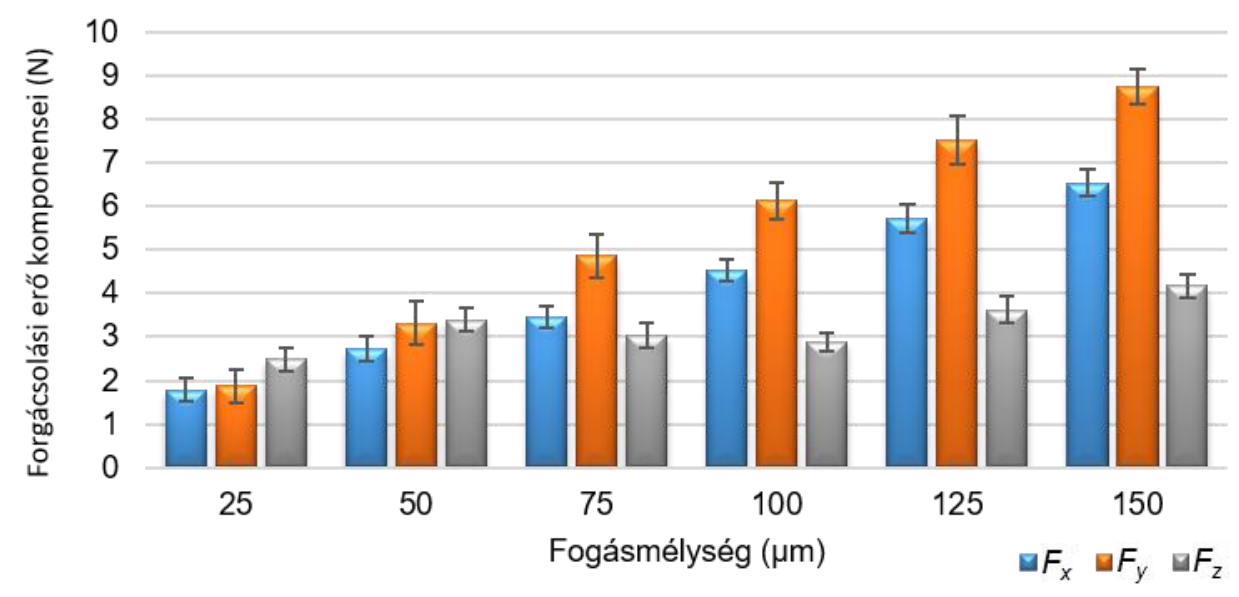

\section{1. ábra. Az erökomponensek alakulása a különböző fogásmélységek esetén}

\subsection{A jellemző erőfrekvenciák elemzése}

A mikromarás folyamatát erőteljes rezgések jellemzik, ezért fontos nagy hangsúlyt fektetni ezek vizsgálatára, mivel az eredmények közvetetten hozzájárulnak a rezgések csökkentési lehetőségeinek kidolgozásához is. A rögzített erőjelek lehetőséget adnak a folyamatot jellemző frekvenciák vizsgálatára is.

Az erőjeleket gyors Fourier transzformáció (FFT) segítségével elemeztük. A 2. ábra FFT diagramok formájában mutatja be reprezentatív mintaként az $F_{x}$ és az $F_{z}$ jelekből a rezgéseket $a_{p}=75$ $\mu \mathrm{m}$ fogásmélység mellett.

A diagramok alapján jól látható, hogy a fordulatszámhoz tartozó frekvencia ( $940 \mathrm{~Hz})$, a kétélü szerszám esetén jellemző élbelépés frekvenciája $(\sim 1880 \mathrm{~Hz})$, illetve ezek felharmonikusai jelennek meg föként a kiugró csúcsok között. Emellett összegyüjtöttük beállításonként az 5 legnagyobb amplitúdójú frekvenciát is mindhárom erőkomponens esetében, amiket a 2. táblázat mutat be a konkrét frekvenciaértékekkel együtt. 

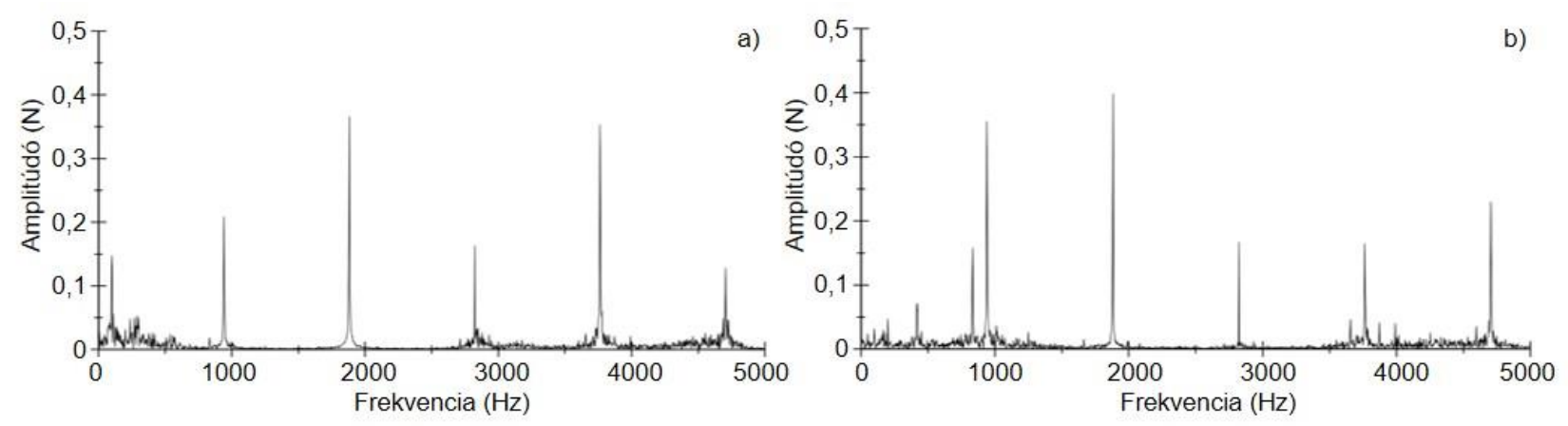

2. ábra FFT diagramok a) $F_{x}$ és b) $F_{y}$ erökomponens esetében $\left(a_{p}=75 \mu \mathrm{m}\right)$

A táblázatban bemutatott értékek nagy része - kékkel jelölve - a folyamat kinematikájához köthető. Az egyéb értékek a megmunkálási környezet sajátosságaiból (pl.: 415 és $830 \mathrm{~Hz}$ ), az elektromos transzformáció miatti rezgésekböl (pl.: $100 \mathrm{~Hz}$ ), illetve a gép szabályozási rendszeréből adódhatnak. A vizsgáltatok alapján nem látható számottevő eltérés a különböző fogásmélységek esetén.

2. Táblázat. A különböző fogásmélységek esetén a jellemző frekvenciaértékek erökomponensenként

\begin{tabular}{|c|c|c|c|c|c|c|c|c|c|c|c|c|c|}
\hline \multirow{2}{*}{$\begin{array}{c}\begin{array}{c}a_{p} \\
(\mu \mathrm{m})\end{array} \\
25\end{array}$} & \multicolumn{4}{|c|}{$\begin{array}{l}\text { Eröfrekvencia, } X \text { irány } \\
(\mathrm{Hz})\end{array}$} & \multicolumn{5}{|c|}{$\begin{array}{l}\text { Eröfrekvencia, } \mathrm{Y} \text { irány } \\
(\mathrm{Hz})\end{array}$} & \multicolumn{4}{|c|}{$\begin{array}{l}\text { Eröfrekvencia, } Z \text { irány } \\
(\mathrm{Hz})\end{array}$} \\
\hline & & 40 & 2 & חתרת מת & & 8 & 1 & 91 & & & 40 & 0 & 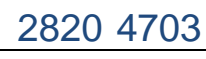 \\
\hline 50 & 40 & 18 & 2 & & & 80 & 940 & 1880 & & & 940 & 1880 & 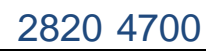 \\
\hline 75 & & 40 & - & & & 7 & 9 & 1 & & 4 & 940 & 1883 & - \\
\hline 100 & 00 & 282 & 940 & 188 & 76 & 940 & 1880 & 28 & 0 & 415 & 940 & 1880 & 4700 \\
\hline $1<5$ & 00 & 940 & 18 & 37604700 & 63 & 80 & 940 & 1880 & 0 & 415 & 940 & 1880 & 4700 \\
\hline 150 & 40 & 1883 & 2823 & 37634703 & 76 & 940 & 1883 & 2823 & 3763 & 834 & 1883 & 2823 & 37634707 \\
\hline
\end{tabular}

A jellemző frekvenciákon túl pedig a folyamat időbeni változásai is a vizsgálataink tárgyát képezte, melyhez folytonos Wavelet transzformáción alapuló idő - frekvencia diagramokat készítettünk. Itt szintén az $a_{p}=75 \mu \mathrm{m}$ fogásmélységet emeltük ki reprezentatív mintaként. A 3. ábrán pedig az $F_{x}$ és $F_{z}$ erőkomponensből származó eredmények láthatóak.
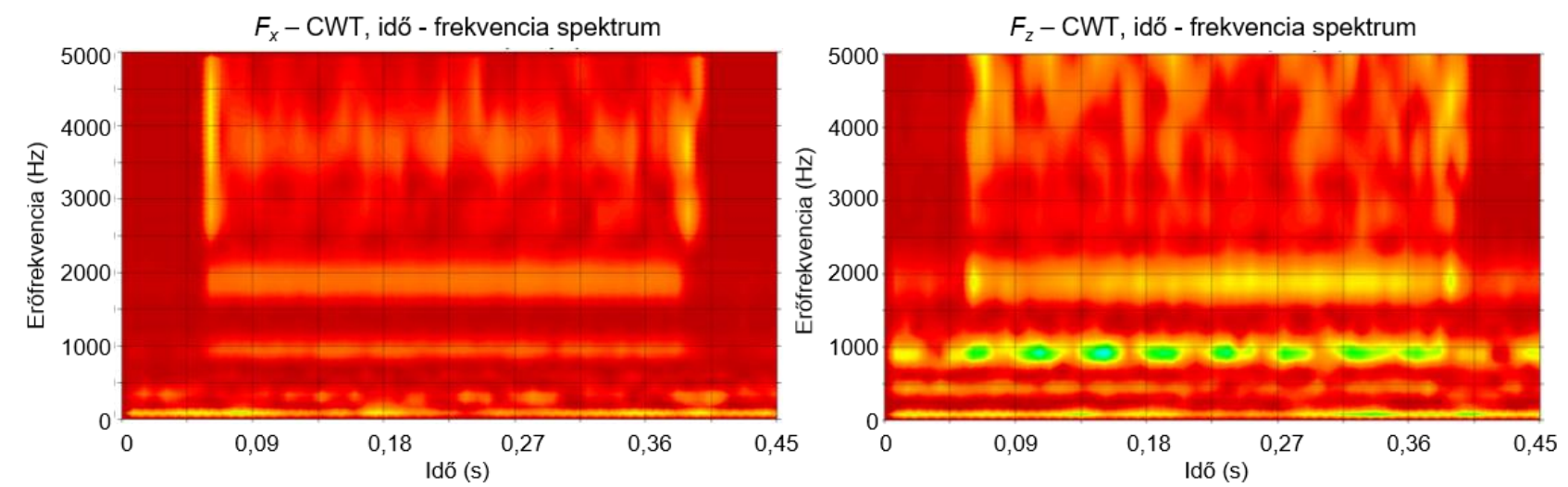

3. ábra Idő - erőfrekvencia diagramok az $F_{x}$ és $F_{z}$ erőkomponenshez $a_{p}=75 \mu \mathrm{m}$ esetén

A diagramok elején és végén ( 0,05 másodperc) forgácsleválasztás nélküli állapot látható, ami ezáltal a megmunkálási környezet alaprezgéseit tartalmazza. Az $F_{x}$-nél a forgácsleválasztás szakaszában a be- és kilépésnél látható erőteljesebb rezgés, ami között kvázi állandósult állapot látható. Ezzel szemben az $F_{z}$ erőkomponens esetében az alaprezgések a nagyobb frekvenciákon is 
megjelennek (föorsó fordulatszám, illetve annak az első harmonikusa). Ebben az esetben a be- és kilépésnél nem látható jelentős különbség, viszont kismértékủ változások megfigyelhetők a fordulatszám frekvenciája közelében, illetve a nagyobb összetevők esetén is.

\section{Összefoglalás}

A vizsgálatok során a mikromarás dinamikai sajátosságait tanulmányoztuk edzett acél, 500 $\mu \mathrm{m}$ átmérőjü szerszámmal történő megmunkálása esetén, ahol különböző fogásmélységeknél elemeztük a forgácsolási erő komponenseit, a folyamatot jellemző erőfrekvenciákat, illetve azok időbeli változásait.

- Az kísérleti eredmények alapján megállapítható, hogy a növekvő fogásmélységeknél, a növekvő forgácskeresztmetszetnek köszönhetően az $F_{x}$ és $F_{y}$ erőkomponensek növekednek.

- Az $F_{z}$ erőkomponens a legjelentősebb a sarokrádiusz értékéig terjedő fogásmélységeknél $\left(a_{p}=25-50 \mu \mathrm{m}\right)$, aminek oka a lokálisan lecsökkent effektív föélelhelyezési szögben rejlik.

- Az erőjelek frekvenciaanalízise alapján az 5 legnagyobb amplitúdójú frekvencia többnyire a technológia kinematikájához tartozik, azonban a megmunkálási környezet sajátosságai is megjelennek az elemzett jelekben.

\section{Köszönetnyilvánítás}

A kutatást részben a K 132430 (Tranziens deformációs, termikus és tribológiai folyamatok kemény fémfelületek finomforgácsolásánál) számú kutatási projekt finanszírozta. A kutatás részben az Innovációs és Technológiai Minisztérium ÚNKP-20-3 és ÚNKP-20-2 kódszámú Új Nemzeti Kiválóság Programjának a Nemzeti kutatási, fejlesztési és innovációs alapból finanszírozott támogatásával készült. A szerzők köszönik Jacsó Ádámnak a kísérletek során nyújtott segítségét, valamint a Fraisa és Böhler cégeknek a támogatást.

\section{Irodalomjegyzék}

[1] Kuzin, V. V., Fedorov, S. Yu., Szalay, T., Farkas, B.: Micromachining of a High-Density Current-Conducting Ceramic With the Use of Electrical-Discharge Machining. Part 1, Refract Ind Ceram, 2016, vol. 57, no. 2, pp. 164-169, DOI:10.1007/s11148-016-9948-Z

[2] Jing, X., Lv, R., Chen, Y., Tian, Y., Li, H.: Modelling and experimental analysis of the effects of run out, minimum chip thickness and elastic recovery on the cutting force in micro-end-milling, International Journal of Mechanical Sciences, 2020, vol. 176, p. 105540, DOI: 10.1016/j.ijmecsci.2020.105540

[3] de Oliveira, F. B., Rodrigues, A. R., Coelho, R. T., de Souza A. F.: Size effect and minimum chip thickness in micromilling, International Journal of Machine Tools and Manufacture, 2015, vol. 89, pp. 39-54, DOI:10.1016/j.jmachtools.2014.11.001

[4] Aramcharoen, A., Mativenga, P. T.: Size effect and tool geometry in micromilling of tool steel, Precision Engineering, 2009, vol. 33, no. 4, pp. 402-407, DOI:10.1016/j.precisioneng.2008.11.002

[5] Balázs, B. Z., Szalay, T., Takács, M.: Investigation of micro milled surface characteristics, Proceedings of Internationa Conference on Innovative Technologies, 2017, pp. 161-164

[6] Kumar, P., Kumar, M., Bajpai, V., Singh, N. K.: Recent advances in characterization, modeling and control of burr formation in micro-milling, Manufacturing Letters, 2017, vol. 13, no. Supplement C, pp. 1-5, DOI:10.1016/j.mfglet.2017.04.002

[7] Ma, L., Howard, I., Pang, M., Wang, Z., Su, J.: Experimental Investigation of Cutting Vibration during Micro-End-Milling of the Straight Groove, Micromachines, 2020, vol. 11, no. 5, Art. no. 5, DOI:10.3390/mi11050494

[8] Wojciechowski, S., Matuszak, M., Powałka, B., Madajewski, M., Maruda, R. W., Królczyk, G. M.: Prediction of cutting forces during micro end milling considering chip thickness accumulation, International Journal of Machine Tools and Manufacture, 2019, vol. 147, p. 103466, DOI:10.1016/j.jmachtools.2019.103466

[9] Biró, I., Szalay, T.: Extension of empirical specific cutting force model for the process of fine chip-removing milling, Int J Adv Manuf Technol, 2017, vol. 88, no. 9-12, pp. 2735-2743,DOI:10.1007/s00170-016-8957-x

[10] Biró, I., Szalay, T., Geier, N.: Effect of cutting parameters on section borders of the empirical specific cutting force model for cutting with micro-sized uncut chip thickness, Procedia CIRP, 2018, vol. 77, pp. 279-282, DOI:10.1016/j.procir.2018.09.015

[11] Takács, M., Balázs, B. Z., Jáuregui, J. C.: Dynamical aspects of micro milling process, Proceedings of International Conference on Innovative Technologies, 2017, pp. 181-184 
[12] Singh, K. K., Kartik, V., Singh R.: Modeling dynamic stability in high-speed micromilling of Ti-6Al-4V via velocity and chip load dependent cutting coefficients, International Journal of Machine Tools and Manufacture, 2015, vol. 96, pp. 56-66, DOI:10.1016/j.ijmachtools.2015.06.002

[13] Mittal, R. K., Kulkarni, S. S., Singh R. K.: Effect of lubrication on machining response and dynamic instability in highspeed micromilling of Ti-6Al-4V, Journal of Manufacturing Processes, 2017, vol. 28, pp. 413-421, DOI:10.1016/j.jmapro.2017.04.007

[14] Câmara, M. A., Rubio, J. C. C., Abrão, A. M., Davim J. P.: State of the Art on Micromilling of Materials, a Review, Journal of Materials Science \& Technology, 2012, vol. 28, no. 8, pp. 673-685, DOI:10.1016/S1005-0302(12)60115-7

[15] https://www.bohler-edelstahl.com/en/product-category/hot-work-tool-steels/ (accessed May 14, 2020).

[16] Balázs, B. Z., Jacsó, Á., Takács, M.: Micromachining of hardened hot-work tool steel: effects of milling strategies, Int J Adv Manuf Technol, Jun. 2020, vol. 108, pp. 2839-2854, DOI:10.1007/s00170-020-05561-x

[17] Balázs, B. Z., Takács M.: Experimental investigation and optimisation of the micro milling process of hardened hotwork tool steel, Int J Adv Manuf Technol, 2020, vol. 106, pp. 5289-5305, DOI:10.1007/s00170-020-04991-x

[18] Balázs, B. Z., Takács M.: A comparative analysis of characteristics of cutting forces at micro-milling of hardened steels, IOP Conf. Ser.: Mater. Sci. Eng., 2020, vol. 903, p. 012056, DOI: 10.1088/1757-899X/903/1/012056

[19] Balázs, B. Z., Takács M.: A minimális forgácsvastagság vizsgálata edzett melegalakító szerszámacél mikromarása esetén, Nemzetközi Gépészeti Konferencia - OGÉT, 2020, pp. 29-32 